\title{
S5ynthesis
}

International Scientific Conference of IT and Business-Related Research

\section{CREATIVITY IN MANAGEMENT: \\ CREATIVE THINKING PROCESS AND BUSINESS MODEL CANVAS}

\author{
KREATIVNOST U MENADŽMENTU: \\ PROCES KREATIVNOG RAZMIŠLJANJA I KANVAS POSLOVNI MODEL
}

\author{
Milena Sokolić \\ Alma Mater Europaea, Department of European Business Studies, Gosposka ulica 1, 2000 Maribor, Slovenia.
}

\begin{abstract}
:
Creativity has gained on its importance in business environment over the past two decades, and has become a popular tool for enhancing innovation not only in design and engineering, but also in management. However, a strong scepticism towards using the approaches based on creativity is still being widely present. This paper analyzes creativity as a characteristic, and thus creative thinking discusses and compares design thinking process and Business Model Canvas (BMC) and their implementation in organisations. This paper analyzes and discusses creativity as an important characteristic of employees and management, which considerably contributes to employee engagement, enhances innovation and strengthens the organisation's strategy or enables creating the new one.
\end{abstract}

Key words:

innovation, strategy, business model.

\section{INTRODUCTION}

Creativity is no longer subject only to artists and innovators. It is also a characteristic of a good leader, effective team-player, productive employee and a strategic tool. While traditional management model "top-down" style is still considered the most trustworthy and realistic, many companies have started changing that. Today's economic situation and saturated markets have forced managers to start thinking differently. According to Smith (2014), they must have the dynamic capability to manage different sources and resources of creativity and innovation that surround the organization and the speed in understanding and solving internal and external issues. However, in current dynamic environment fostering consumerism more than ever before and fast growing markets triggering competition to think and react even faster, there is a necessity for managers to give themselves an opportunity to think differently and give more credibility to adapting different creative processes in order to enhance innovation.

\section{CREATIVITY IN ORGANISATIONS AND CREATIVE THINKING}

There are many definitions of creativity, and the cornerstone in each one of them is the term "generation of ideas". Oldham and Cummings (1996) explain creativity as generating ideas, procedures, or products that are new or original, and potentially relevant for, or useful to an organization, while Franken (2007) describes it as a tendency to generate or recognize ideas, alternatives, or possibilities and emphasizes the generation of those

\section{Apstrakt:}

U protekle dve decenije kreativnost dobija sve više na značaju u poslovnom okruženju, i postaje često korišćeno sredstvo za unapređenje inovacija ne samo u oblasti dizajna i inženjerstvu već i u menadzmentu. Međutim, i dalje je prisutan izražen skepticizam prema pristupima koji se baziraju na kreativnosti. Ovaj rad analizira kreativnost kao karakteristiku, i u njemu se razmatra i upoređuje process kreativnog razmišljanja (design thinking) i Kanvas poslovni model, kao i njihova primena u organizacijama. Ovaj rad analizira kreativnost kao važnu karakteristiku zaposlenih kao i menadzmenta, koja u velikoj meri doprinosi angažovanju zaposlenih, povećava inovativnost, i jača strategiju organizacije i čak doprinosi kreiranju nove.

\section{Ključne reči:}

inovativnost, strategija, poslovni model.

ideas that may be useful in solving problems, communicating with others, and entertaining ourselves and others.

As Dufor and Steane (2014) used Picasso's drawings and paintings as a metaphor for strategic problems and conclude that it is not the strategic planning and programming to be blamed for problems that occur in organisations, but the lack of creative strategic thinking. Studies (Zhou, 2008) have demonstrated that providing the working environment with creative co-workers enhances employee creativity. Moreover, employees with less creative personalities performing while creative co-workers were present and more supervisors provided developmental feedback, the more employees exhibited creativity. However, once creativity has been unleashed, it needs to be applied.

While each person has unique approach to problem-solving, which depends on its character, experience, environment etc., Robson (2002) distinguished between three different types of thinking:

- analytical thinking, which is used by the majority of people when facing a problem. It is a spontaneous approach people will use due to the schooling, which still exerts a major impact on solving problems analytically;

- lateral thinking represents analytical thinking, but as expressed by Robson, it allows creativity to some extent in order to give the insight needed to get on the right wavelength;

- creative thinking gives most space for finding a solution and although it will be approached creatively, it does not mean that analytical problem-solving skills will not be used. Design thinking comes out of creative thinking. 
A special subcategory of creative thinking, called design thinking, has been developed in early nineties with the purpose of finding solutions in business incorporated by design and innovation consulting firm IDEO. The process itself has been incorporated by large corporations such as Apple, IBM, Samsung, Procter \& Gamble etc.

Design thinking is known as a solution-based problemsolving process. Brown (2008) defined it as a discipline that uses the designer's sensibility and methods to match people's needs with what is technologically feasible and what a viable business strategy can convert into customer value and market opportunity. Thinking like a designer, who possesses empathy, integrative thinking, optimism, experimentalism, collaboration, can transform the way you develop products services, processes, and even strategy. According to Jones (2009), design thinking on one side characterizes innovative, human-centred enterprises that form part of the so-called architecture, design and anthropology paradigm, while on the other hand, it focuses on a collaborative and iterative style of work and a mode of thinking similar to practices associated with more traditional so-called management, economics, psychology paradigm.

Hasso Plattner Institute of Design at Stanford has developed a whole new educational programme called d.school that provides students and professionals of all disciplines with the knowledge of design thinking. It is described as human-centred five-stage process (2015), which involves:

- empathizing with people that are part of design challenge by observing, engaging, watching and listening;

- defining the problem statement, the user as well as the needs, expressing insights gathered through empathy and research;

- ideation by brainstorming in order to transit from identifying problem to creating solutions;

- prototyping by creating cheap but useful solution that will enable to receive a feedback;

- testing by generating another opportunity according to feedback of the prototype.

While the process described arises from the research programme that strives to apply rigorous academic methods to understand how and why design thinking innovation works and fails (Hasso-Plattner-Institut, 2015), the process aimed especially in the organizational context is more structured as shown in Pic. 1 below (Liedtka \& Oglieve, 2011): during a process of design thinking, ten tools lead through the four-stage, respectively five-stage, and taking into account that the process starts with visualization. These tools create new possibilities and reduce risk when managing the inevitable uncertainty of growth and innovation, but each stage can relate to the stages described in the process taught at d.school.

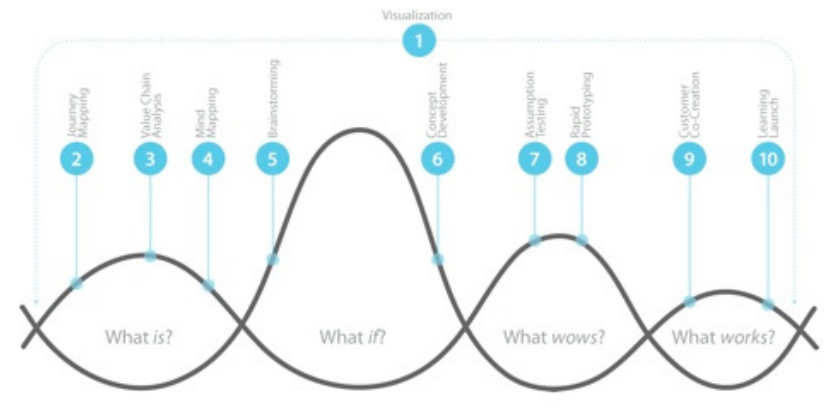

Picture 1: Ten tools through four stages in design thinking process

Source: Liedtka \& Ogilvie, 2011.
Roger Martin (2009), as one of the leading experts of design thinking, says that the nature of wicked problems, which represent complex problems that have not been treated with much success because they won't keep still (Ritchey, 2013), need to be understood before solving it. In order to achieve that, "the knowledge funnel", as called by Martin, needs to be enforced in order to recognize possible solutions. The knowledge funnel starts with exploration, heuristic implemented into action, revision, and conversion of heuristic into algorithm.

According to empirical examination by Wattanasupachoke (2012), the use of design thinking in business management and operations can increase innovativeness in the company through creativity, which leads to better financial performance in the future. However, examination also concludes that design thinking does not have a direct relationship with performance due to its focus on improving the operating process and developing creativity in product and service design.

Design thinking can be used as a useful tool in Business Model Canvas (BMC). BMC is a new model, developed in 2008 by Osterwalder and Pigneur (2010), and it represents a strategic management tool in the form of a visual chart or rather template (Pic. 2), which identifies nine different features within three different dimensions - creation, capture and delivery of value:

- key partners and suppliers,

- key activities, customer relationships and revenue streams linked to those activities,

- value propositions of products and services delivery to each customer segments,

- key resources required for value propositions,

- customer segments to be reached,

- customer relationships, which are expected from customer segments to be established,

- channels through which customer segments want to be reached,

- cost structure that will support business model,

- revenue stream contribution to overall revenues, for what and how are customers paying.

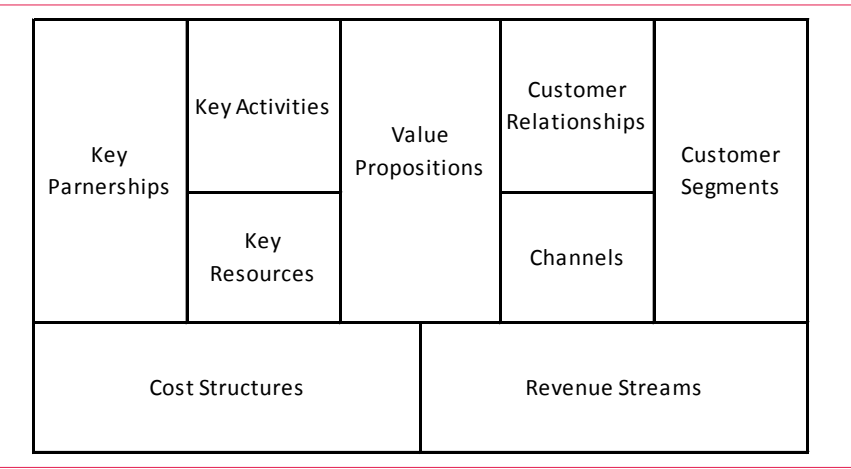

Picture 2: Business Model Canvas template

Source: Adapted from Osterwalder \& Pigneur, 2010.

\section{DISCUSSION}

The implementation of creative thinking into an organization and its processes can be very challenging. The presence of creative co-workers has positive effects on non-creative employees (Zhou, 2008). Shaping of an appropriate environment and focusing on employee skills can unveil the existing potential and encourage development of new ones, which will ultimately lead to better communication, stronger team work, greater effectiveness and higher productivity. However, the adaptation to 
that kind of a mindset does not only depend on the nature of organisation's products or services, but also on the resources of an organisation and the willingness of management to adapt to a creative mindset. The common description of creative thinking definitions - generating idea, requires specific characteristics that creative thinking should possess in order to be able to apply creative thinking to business processes. Analytical thinking has always been an essential requirement of the employers when looking for employees, but creativity is also becoming one of those requirements. When looking for the evidence of creative thinking in practice, we came across the fact that creativity is requested, or rather desired as one of the skills among management vacancies. Roche, the leading pharmaceutical company, states on its career website that their Principal Program Manager should understand and experience design thinking and usability, or in other words, a user- centred design techniques (Roche, 2015).

Many organisations succeed by applying design thinking, and one of them is Apple. With the support of IDEO, Apple's mouse was the first product designed based on design thinking principles, which continued to launch products and generate success on the market, whose reasoning stands behind the process of design thinking (Ideo, 2015). Forty years ago, when Apple entered the market, the business processes and systems that evolved the development of IT market for personal computers were, as explained in the case study of Thomke and Feinberg (2012), captured in enterprise software, with an emphasis on automating tasks. Findings of the case study show that Apple's approach was different. They were aware that they have to focus on their product's potential users, so they first started developing design based on what they thought people would need and want and the way people would interact with the computer. Prior to finding the right solution, Apple tried many options, as a result of creativity integration.

However, Apple is not the only organisation that tried to solve its problems with creative approach. One of them is also Procter and Gamble (P\&G). According to Kotchka (2008), P\&G needed a culture change and built the design into DNA of the organisation based on the initiative of the CEO, Lafley. They became aware that despite the fact that they were the first company that used mass marketing and despite the resources and modern technology possessed, they will not be able to keep up with the market changes unless the focus is placed on the consumer. $P \& G$ went through the design thinking approach, which ultimately lead to a change in the entire organisation and their products. This was achieved by focusing more on the consumers by observing them and designing for them, but also by hiring experts and focusing on employees by educating them through brainstorming, mentor-up programme, reorganizing and redesigning working space. Martin (2009), also a team member of $\mathrm{P} \& \mathrm{G}$, who formed the process of design thinking applied to $P \& G$ 's products redesign, says that design thinking for businesses comprises three components: (1) deep and holistic user understanding, (2) visualization of new possibilities, prototyping, and refining, and (3) the creation of a new activity system to bring the nascent idea to reality and profitable operation. Since $P \& G$ redesigned its products and advertising, recognition and reputation of its brands has increased, e.g. the shampoo Herbal Essences, it was just before the removal from the market and organisation's product line when $P \& G$ decided to redesign the entire appearance of the product and its advertising. A similar occurred to their Oil of Olay cream, which was completely redesigned and many other products (Kotchka, 2008).

Another example shows that British Airways managed to transform travelling experience of its customers with the help of design thinking through consultancy firm. Twenty years ago, the company introduced the world's first fully flat beds in their first class, and five years later in business class, which raised the standards in air travelling and encouraged their competitors to follow this adaptation (Holland \& Busayaean, 2014). In 2012, the company redesigned the check-in area in Paris Charles de Gaulle airport in collaboration with consultancy that specialises in using design thinking to reposition clients and provide competitive edge (British Airways, 2015).

Academicians and practitioners are being very collaborative when it comes to design thinking. David Kelly, a founder of IDEO, teaches students, as well as executives at d.school at Stanford. P\&G has asked d.school, Illinois Institute of Design and Rotman School of Management, to design a course for P\&G's business leaders. The participants have been introduced to design thinking in a few day of workshops through design thinking steps, from brainstorming, prototyping etc., while other employees were then introduced to a problem and led towards problem-solving through design thinking methodology, but were not told about the methodology. According to Kotchka (2008), learning was very successful and this approach has been present in $P \& G$ for a decade now.

There are significantly more organisations that have applied the approach of design thinking to their business processes, and increased innovation, but majority of them are large, global corporations, where technology and its development play an important role in their processes. Those corporations also have the resources to fund those processes, which requires engagement of experts from different disciplines involved in several-stage and timely processes. This clearly represents a disadvantage for smaller organisations.

When we tried to infer and analyze steps of design thinking application in each of these studies, no detailed information about the procedures could be found. In order to receive a complete insight into how design thinking works in practice and understand its complexity, the actual presence with observation would be needed.

Although design thinking process can be time-consuming, the process itself is learned through its implementation and is also costly. The BMC, which is also the result of creative thinking, offers simple, easy and quick insight into an organization's qualities, capacities and abilities. This can be reached by filling the predesigned scheme, which also has limitations.

Since creative thinking allows numerous ideas that can be non-systematic and in order to be equally valued until they have been tested, it is necessary to assume a more systematic creative thinking approach. Identified stages of design thinking can lead a challenge taker to concrete and desired results, provided he/ she is carefully following. A challenge taker can move towards the realization or completion of the process when ready, but still keep it structured. Design thinking can be useful when assessing characteristics and parameters to BMC, which covers the majority aspects of the organization and it can work well with SWOT analysis. Working in combination can form a good strategy plan or strengthen the existing one. While revising organization's strengths, weaknesses, opportunities and limitations, the questions related to each aspect of BMC can give a good picture of the model itself, but it can also open some issues or questions that were not assessed in SWOT analysis and vice versa.

Little academic research on BMC has been done so far. Despite BMC being relatively new, it adhered very quickly amongst organisations due to its simplicity. Organisations such as IBM, Ericcson, Public Works and Government Service of Canada have used BMC (Osterwalder \& Pignueur, 2009), while Deloitte also proposed a BMC as part of the business plan for their 
technology talent competition. Carefully provided information for BMC can build a strong foundation for organisation's strategy. Zandoval and Zilber (2014) conclude that this model is the most complete business model compared to several others since it contains all internal and external organizational components in detail, and shows how these relate to creation and capturing the value proposed by the organization. Although the model is simple and practice-oriented, which enables possibility to start from the scratch and is more applicable for innovation than for transformation of the existing models, it does not give a broader analysis of competition and its structures. Moreover, it does not formulate goals nor takes key performance indicators into account, nor it does performance measurements (Spanz, 2012).

Before the application of a new way of thinking, either using the methodology of design thinking, or starting to fill the template for $\mathrm{BMC}$, people assigned to those processes need to be fully familiar or either led through (design thinking methodology) or taught about the process (BMC).

\section{CONCLUSION}

Encouraging creativity in the workplace has been given a lot of attention in the last two decades. It plays an important role in business environment since it increases peoples' engagement, improves communication, strengthen team collaboration and consecutively leads to higher productivity. Design thinking, as a subcategory of creative thinking, is a structured solution-based problem-solving process that can be used with any discipline, service or product, can positively contribute to a design challenge undertaken by an organization, whether it refers to reorganizing a department or developing a new product, but it should not completely exclude the analytical problem solutions. Several organisations, especially the larger ones, have applied design thinking to their processes, which led to positive solutions. While design thinking itself can take a lot of time within the entire process and can be more costly, Business Model Canvas is a strategic management model that is easy to use, and it enables an organization to recognize its potentials and encourage innovation and growth through creative thinking.

Resources that are limited and difficult to measure, as well as recent demand and popularity of creative thinking, make an abundance of opportunities for future research regarding creative thinking, techniques and approaches.

\section{REFERENCES}

Applying Design Thinking to Your Business. (2009). An Interview with Roger Martin. Retrieved April 5, 2015, from https:// hbr.org/2009/11/applying-design-thinking-to-yo.

Brown, T. (2008). Design Thinking. Harvard Business Review. Retrieved April 6, 2015, from http://www.fredonia.edu/pr/web/ pdf/HBR-Timbrown.pdf

British Airways. (2014). Check-in at Paris Charles de Gaule. Retrieved April 6, 2015, from http://www.britishairways.com/ en-fr/offers/local/changes-at-cdg-airport.

Ching, Y. H., \& Fauvel, C. (2013). Criticism, variations and experiences with Business Model Canvas. European Journal of Agriculture and Forestry Research, 1(2), 26-37.

Deloitte. (2015). Deloitte Top Technology Talent Competition. Retrieved April 16, 2015, from http://www2.deloitte.com/ content/dam/Deloitte/ie/Documents/Technology/2014_ top_tech_entry_form_deloitte_ireland.pdf.

Dufour, Y., \& Steane, P. (2014). Creative strategic thinking and sustainable leadership: lessons from Picasso. Journal of Global Responsibility, 5(2), 219-225.
Franken, E.R. (2007). Human Motivation. Belmont: Thomson/ Wadsworth.

Hasso Platnner Institut. (2015). Design Thinking Research Programm. Retrieved March 12, 2015, from http://hpi.de/en/ dtrp/program/overview.html.

Holland, R., \& Busayawan, L. (2014). Managing Strategic Design. London: Palgrave.

IDEO. (2015). Retrieved March 12, 2015, from http://www.ideo. $\mathrm{com} /$

Plattner, H. (2015). Institute of Design at Stanford. Retrieved March 12, 2015, from http://dschool.stanford.edu/

Jones, A. (2008). The Innovation Acid Test. Axminster: Triarchy Press.

Liedtka, J. \& Ogilvie, T. (2001). Designing for Growth: A Design Thinking Tool Kit for Managers. New York: Columbia Business School Publishing.

Kotchka, C. (2008). Lecture at Institute of Design Conference 2008. Retrieved April 12, 2015, from https://vimeo.com/5203345.

Martin, R. (2009). The Design of Business: Why Design Thinking Is the Next Competitive Advantage. Boston: Harward Business Review Press.

Oldham, G. R., \& Cummings, A. (1996). Employee creativity: Personal and contextual factors at work. Academy of Management Journal, 39 (3), 607B634.

Osterwalder, A. \& Pigneur, Y. (2010). Business Model Generation: A Handbook for Visionaries, Game Changers, and Challengers. Hoboken: John Wiley \& Sons.

Ritchey, T. (2013). Wicked problems: Modelling Social Messes with Morphological Analysis. Acta Morphologica Generalis, 2 (1), n.p.

Financial Times. (2008). Procter \& Gamble hires design outsider. Retrieved April 5, 2015, from http://www.ft.com/ $\mathrm{cms} / \mathrm{s} / 0 / 386 \mathrm{~b} 4 \mathrm{f1}$ e-2761-11dd-b7cb-000077b07658. html\#axzz3WoSFusH4.

Roche. (2015). Careers. Retrieved April 5, 2015, from from http://www.roche.com/careers/jobs/jobsearch/job.htm?id=G00435803\&locale $=$ en $\&$ title $=$ Principal $\% 20$ Program\%20Manager\%20-\%20Emerging\%20Health\%20 Technology.

Robson, M. (2002). Problem-solving in Groups. Burlington: Ashgate Publishing Company.

Smith, E.P. (2014). Strategic Human Resource Management: An International Perspective. London: SAGE Publications Ltd.

Spanz, G. (2012). Startup best practice: Business Model Canvas. Retrieved April 6, 2015, from http://blog.ventureworks.ch/ post/18727255435/startup-best-practice-business-modelcanvas

Thomke, S., \& Feinberg, B. (2012). Design Thinking and Innovation at Apple. Harward Business School Cases 9-609-066.

Wattanasupachoke, C. (2012). Design Thinking, Innovations and Performance: An Empirical Examination. International Journal of Management and Innovation, 4(1), 1-14.

Zandoval Bonazzi, F.L. \& Zilber, A.M. (2014). Innovation and Business Model: a case study about integration of Innovation Funnel and Business Model Canvas. Review of Business Management, 16(53), 616-637. DOI: 10.7819/rbgn. v16i52.1812.

Zhou, J. (2003). When the presence of creative coworkers is related to creativity: Role of supervisor close monitoring, developmental feedback, and creative personality. Journal of Applied Psychology, 88(3), 413-422. 